\title{
Field Application of Calcium to Reduce Phytophthora Stem Rot of Soybean, and Calcium Distribution in Plants
}

T. Sugimoto, Hyogo Agricultural Institute for Agriculture, Forestry and Fisheries, 1533 Minamino-oka, Befu, Kasai, Hyogo 679-0198, Japan; K. Watanabe, Hyogo Agricultural Institute for Agriculture, Forestry and Fisheries, and Tokyo University of Agriculture, Department of Applied Biology and Chemistry, 1-1-1 Sakuragaoka, Setagaya-ku, Tokyo 156-8502, Japan; S. Yoshida and M. Aino, Hyogo Agricultural Institute for Agriculture, Forestry and Fisheries; M. Furiki and M. Shiono, Hitachi High-Technologies Corporation, 11-1 Ishikawa, Hitachinaka, Ibaraki 3120057, Japan; T. Matoh, Kyoto University, Laboratory of Plant Nutrition, Division of Applied Life Sciences, Graduate school of Agriculture, Oiwake, Kitashirakawa, Sakyo-ku, Kyoto 606-8502, Japan; and A. R. Biggs, West Virginia University, Kearneysville Tree Fruit Research and Education Center, P.O. Box 609, Kearneysville, WV 25430

\begin{abstract}
Sugimoto, T., Watanabe, K., Yoshida, S., Aino, M., Furiki, M., Shiono, M., Matoh, T., and Biggs, A. R. 2010. Field application of calcium to reduce Phytophthora stem rot of soybean, and calcium distribution in plants. Plant Dis. 94:812-819.

The effect of calcium compounds $\left[\mathrm{Ca}(\mathrm{HCOO})_{2}-\mathrm{A}\right.$ and $\left.\mathrm{Ca}\left(\mathrm{NO}_{3}\right)_{2}\right]$ on the incidence of Phytophthora stem rot of soybean (Glycine max) cv. Tanbakuro was investigated in the field. Disease incidence in control plants in three fields naturally infested with Phytophthora sojae ranged from 11.7 to $52.0 \%$ at 140 days after transplanting. Independent of the pathotype diversity, 4 and 10 $\mathrm{mM}$ of the calcium compounds applied twice (prior to transplanting and 14 days after transplanting) significantly suppressed disease incidence and delayed onset. $\mathrm{Ca}(\mathrm{HCOO})_{2}-\mathrm{A}$ (Suicaru) was more effective than calcium nitrate for reducing disease incidence. In most cases, the calcium amendments increased plant height, number of nodes and pods, and seed yields, and reduced low-quality seeds. Scanning electron microscopy with fresh samples showed increased accumulation of calcium crystals around the cambium and xylem elements of soybean plants treated with $10-\mathrm{mM} \mathrm{Ca}(\mathrm{HCOO})_{2}-\mathrm{A}$ and $\mathrm{Ca}\left(\mathrm{NO}_{3}\right)_{2}$. Mycelial penetration was inhibited at these sites. These results indicated that calcium-rich areas may be more resistant to invasion by $P$. sojae, and the calcium crystals may play an important role in calcium ion storage and its availability for those tissues to maintain long-term field resistance.
\end{abstract}

Phytophthora stem rot, caused by the soilborne fungus Phytophthora sojae (21), is one of the most destructive diseases of soybean (Glycine max (L.) Merr.) and is widely distributed in several soybeanproducing areas around the world (39). The pathogen can attack and kill soybean plants at any stage of growth (10), and it causes \$251.6 million in annual yield losses in the United States (52).

This disease also is one of the most important soybean diseases in Japan (44). It was first observed in 1977 in Hokkaido (49) and has been widespread and increasing in other areas of Japan (44). Glycine max cv. Tanbakuro, which is a commercial black soybean cultivar in Japan, is mainly produced in the Sasayama region of Hyogo, and is used for edamame and seed processing (15). This soybean cultivar is highly prized because its seeds are much

Corresponding author: Takuma Sugimoto E-mail: Takuma_Sugimoto@pref.hyogo.lg.jp

Accepted for publication 19 February 2010.

doi:10.1094/PDIS-94-7-0812

(c) 2010 The American Phytopathological Society larger than those of other soybean cultivars, weighing about 70 to $85 \mathrm{~g}$ per 100 seeds, and a higher premium is paid than for other cultivars. It was recently reported that black soybeans have many positive effects on the human body (46), and thus they are widely sold in Japan. Despite these favorable traits, this cultivar is very susceptible to $P$. sojae (44). In recent years, yields of soybean and the income of soybean producers have been decreasing considerably because of this disease.

We previously reported that calcium compounds could reduce the severity of Phytophthora stem rot of soybean (42). Application of all concentrations $(0.4,4$, $10,20 \mathrm{mM}$ ) of five formulated calcium products $\left[\mathrm{Ca}(\mathrm{HCOO})_{2}-\mathrm{A} \quad\right.$ (Suicaru), $\mathrm{Ca}(\mathrm{HCOO})_{2}-\mathrm{B}$ (Baicaruty), $\mathrm{Ca}(\mathrm{HCOO})_{2-}$ $\mathrm{C}$ (Hicaruku), $\mathrm{CaSO}_{4}$-A (Cell-Bine), and $\mathrm{CaCl}_{2}$-A (Kalklon)] and two chemical compounds $\left[\mathrm{CaCl}_{2}\right.$ and $\left.\mathrm{Ca}\left(\mathrm{NO}_{3}\right)_{2}\right]$ prior to inoculation greatly suppressed disease incidence in laboratory experiments with pathogen mycelium. $\mathrm{Ca}(\mathrm{HCOO})_{2}-\mathrm{A}$ (Suicaru: a commercially available calcium formate product) was the most effective in suppressing disease incidence among all seven calcium compounds tested. Seedling tray experiments with zoospores indicated that $10 \mathrm{mM} \mathrm{Ca}(\mathrm{HCOO})_{2}-\mathrm{A}$ was more effective for reducing disease incidence under growth chamber conditions. However, the effect of these compounds on the incidence of Phytophthora stem rot has not been studied in field settings. The impact of calcium amendments on disease incidence and agronomic traits, and the effective concentration still need to be determined in the field, where several $P$. sojae races (pathotypes) may exist.

The mechanisms involved in disease reduction of Phytophthora stem rot on soybean in the laboratory or growth-chamber experiments are due to multiple effects of direct suppression on zoospore release and fungal growth in combination with increased calcium uptake by plants $(40,42)$. High levels of calcium solutions significantly inhibited mycelial growth and zoospore release by $P$. sojae. However, the response of the host plant tissue to calcium compounds has been unclear, and further research is needed on the localization and distribution of calcium in soybean plants.

Preferential localization of certain ions has been reported in various host-pathogen combinations (24). Among these, localization of $\mathrm{Ca}^{2+}$ has been studied most extensively at the cellular level. Kunoh (24), using X-ray microanalysis coupled with the scanning electron microscope (SEM), reported that $\mathrm{Ca}^{2+}$, as well as $\mathrm{Si}^{4+}$ and $\mathrm{Mn}^{2+}$, were localized in a halo surrounding the penetration site of Erysiphe graminis in the epidermis of barley. The accumulation of various inorganic elements near penetration sites or diseased organs or tissues also has been reported (24). Scanning electron microscopy using fresh samples indicated marked accumulation of potassium at the penetration-stopping sites of $P$. sojae in the cortex layer of soybean plants treated with $30 \mathrm{mM} \mathrm{KNO}_{3}$, compared with the nontreated control plants (41). SEM observation of conidia on strawberry leaves showed that soluble potassium silicate inhibited penetration of strawberry leaves by the powdery mildew fungus (20). Accumulation of silicon also has been observed with SEM at the penetration 
sites of Magnaporthe grisea on fresh paddy rice leaves (27).

The objectives of this study were to (i) investigate the efficacy of a commercial calcium product $\left[\mathrm{Ca}(\mathrm{HCOO})_{2}-\mathrm{A}\right.$ (Suicaru)] and a chemical compound $\left[\mathrm{Ca}\left(\mathrm{NO}_{3}\right)_{2}\right]$ on disease reduction, plant traits, and seed yields of cv. Tanbakuro (black soybean) in the field from 2007 to 2008, (ii) examine pathogenic diversity of $P$. sojae in the experimental fields, and (iii) determine the localization and accumulation of calcium with SEM observation in soybean seedlings to investigate possible mechanisms involved in disease reduction by calcium application. This is the first report concerning the relationship between calcium compounds and Phytophthora stem rot disease on soybean in the field.

\section{MATERIALS AND METHODS}

Field experiments. Experiments to examine the effect of calcium applications on the reduction of Phytophthora stem rot were conducted in three trials at Kawakita $\mathrm{K} 1$, Yakami, and Kawakita K2, in the Sasayama region of Hyogo in 2007 (Kawakita K1) and 2008 (Kawakita K2 and Yakami areas). The Sasayama region consists of clay soil naturally infested with $P$. sojae (T. Sugimoto and K. Watanabe, preliminary experiments, data not shown). Fields were planted to rice prior to the current experiments. Cultivation of soybean was carried out using the conventional method in this region (18).

Black soybeans are usually sown in a plastic tray and transplanted into a field in Hyogo, because the soybean cultivation system is very intensive in this region. Soybean plants for the field experiments, 128 soybean seeds (cv. Tanbakuro), were placed on autoclaved vermiculite in a 128well seedling tray (each cell size: $2 \times 2 \times 4$ $\mathrm{cm})$ with one seed per cell. The seedling tray was placed on a large plastic tray to maintain soil moisture. Five days after sowing, the seedlings were treated with $1,000 \mathrm{ml}$ of various concentrations $(0,4$, and $10 \mathrm{mM}$ ) of $\mathrm{Ca}(\mathrm{HCOO})_{2}-\mathrm{A}$ (Suicaru) or $\mathrm{Ca}\left(\mathrm{NO}_{3}\right)_{2}(\mathrm{pH}=5.8)$ per each tray and placed in the greenhouse at 23 to $25^{\circ} \mathrm{C}$. Ten days after calcium treatments, the soybean seedlings in each tray were transplanted to the fields at a seedling density of 60 plants per $30-\mathrm{m}$ row with a row width of $150 \mathrm{~cm}$ in each plot on 25 June 2007 and 26 June 2008. Fourteen days after transplanting, the seedlings were treated again with $500 \mathrm{ml}$ of 0,4 , and 10 $\mathrm{mM}$ calcium solution per each seedling by hand. All plots were arranged in a randomized complete block design with three replications in each field. The plots were examined periodically to determine stand losses that were caused by Phytophthora stem rot. Disease incidence, calculated as the ratio of dead plants to the initial 60 plants in each plot, was measured 11 times from 25 June to 7 November 2007, and 15 times from 26
June to 13 November 2008. Final disease incidence was evaluated on 7 November 2007 and 13 November 2008. Nontreated plants of cv. Conrad, which shows a high level of partial resistance to $P$. sojae (10), was employed under the same conditions to compare with calcium applications.

Chemical properties of soils. Field soils were obtained from three experimental fields in Sasayama on 15 May 2007 (Kawakita K1) and 13 May 2008 (Kawakita K2 and Yakami) just before transplanting the soybean seedlings. Soil was sampled from five random locations (20 $\mathrm{cm}$ deep) in each field. Soil chemistry analysis was conducted according to the method of Baysal et al. (3) with small modifications. Briefly, the soil samples were dried at room temperature for a week, then ground and passed through a 2-mm sieve. $\mathrm{pH}$ was analyzed in a 1:2.5 (wt/wt) water suspension with a $\mathrm{pH}$ meter (HM30s model; TOA, Tokyo, Japan). Cation exchange capacity (CEC) and exchangeable cations $\left(\mathrm{CaO}, \mathrm{MgO}, \mathrm{K}_{2} \mathrm{O}\right)$ were measured by a shaking extraction method (32). Electrical conductivity and available phosphorus were analyzed via the Truog method (48). Phosphate absorption coefficient (PAC) was determined by an orthophosphoric acid method (37). The extractable ions $(\mathrm{Cu}, \mathrm{Zn}, \mathrm{Mn}$, and $\mathrm{B})$ were analyzed by the ICP-AES (13).

Pathotypes of $\boldsymbol{P}$. sojae isolates. Ten diseased soybean plants (cv. Tanbakuro) in each of the three experimental fields in Hyogo were collected in late August 2007 and 2008. Isolation from the different diseased plants was carried out according to the previous study (44). Thirty isolates (10 from each of three fields) were subsequently derived and used for the following virulence tests. The virulence of each isolate was evaluated using the hypocotyl inoculation method (25) modified by Sugimoto et al. (44,45). G. max cv. Tanbakuro and cv. Williams (rps) were used as susceptible control plants during virulence tests. The pathotypes of the isolates were examined on the following 14 differentials: L88-8470 (Rpsla), L77-1863 (Rpslb), L75-3735 (Rpslc), PI103091 (Rpsld), L77-1794 (Rpslk), L76-1988 (Rps2), L83-570 (Rps3a), L91-8347 (Rps3b), L92-7857 (Rps3c), L85-2352 (Rps4), L85-3059 (Rps5), L89-1581 (Rps6), L933258 (Rps7), and PI399073 (Rps8). Thus, race (U.S.) of each isolate was determined by the reactions of standard sets of 8 of the 14 Rps differentials (14). More than 10 seeds per each differential cultivar were used for the virulence test. About 7 days after inoculation, the number of dead or surviving plants in each cultivar was recorded, and cultivars were rated as resistant or susceptible. Each cultivar was considered resistant (R) or susceptible (S) according to the method of Sugimoto et al. (44). Bioassays were repeated three times with two replications.
Effect of calcium applications on plant traits and seed yields. The effects of calcium applications $\left[\mathrm{Ca}(\mathrm{HCOO})_{2}\right.$ and $\left.\mathrm{Ca}\left(\mathrm{NO}_{3}\right)_{2}\right]$ on several plant traits and seed yields of cv. Tanbakuro were evaluated based on the results at Kawakita K2 and Yakami regions in 2008. Twenty individual plants were randomly collected from each of the soybean plots. Data of flowering for each plot was measured periodically in late July to early August. Maturity was recorded when $95 \%$ of the pods had obtained brown mature color. Plant height was measured in late October as height of an average plant from ground level to the uppermost node. Diameter of the main stem was measured in late October as the diameter at the cotyledonary node. At the R8 stage (11), the 20 plants were harvested from each plot, and all pods were carefully removed from each plant after sufficient drying in a greenhouse under natural conditions. Thus, numbers of nodes and pods were counted, and total seed yield per plant was measured. Soybean seed quality was evaluated visually based on the degree of thinner, wrinkling, defective seed coats and moldy or rotten seeds according to the guidelines by Tewari et al. (47). The weight of low-quality seeds per plant was determined, and then good seed yield per plant was calculated as follows: total seed yield soybean seed of low quality. Then, good seed weight was measured as grams per 100 seeds. The measurements were conducted two times in three replications at each of the different calcium concentrations.

Scanning electron microscopy. Inoculated and noninoculated soybean seedlings treated with or without calcium solutions $\left[0\right.$ and $10 \mathrm{mM} \quad \mathrm{Ca}(\mathrm{HCOO})_{2}-\mathrm{A}$ or $\left.\mathrm{Ca}\left(\mathrm{NO}_{3}\right)_{2}\right]$ were used for measurements of soybean stem structure and calcium accumulation using SEM analysis. Each treatment was conducted in a test bottle under laboratory conditions using the modified agar medium inoculation method (41) as described previously. Briefly, one $P$. sojae isolate (race 39) was chosen for the inoculation test from 30 isolates that were used for pathotype determination as described above because it showed highly aggressive growth on cv. Tanbakuro (100\% disease incidence at 10 days after inoculation). Eight soybean seeds (surface sterilized with $1.0 \% \mathrm{NaOCl}$ ) of cv. Tanbakuro per each treatment were sown on autoclaved $0.7 \%$ water agar medium $(130 \mathrm{ml}$ total volume) containing $1.0 \%$ (wt/vol) sucrose and 0 or $10 \mathrm{mM} \mathrm{Ca}(\mathrm{HCOO})_{2}-\mathrm{A}$ and $\mathrm{Ca}\left(\mathrm{NO}_{3}\right)_{2}(\mathrm{pH}=5.8)$ in a test bottle (diameter $=8 \mathrm{~cm}$, height $=20 \mathrm{~cm}$ ) and incubated at $23^{\circ} \mathrm{C}$. After the first primary leaf appeared, approximately 10 days after sowing, the stem of the soybean near ground level was covered with two 3-mmdiameter plugs of 10-day-old mycelium of $P$. sojae isolate cultured on diluted potato dextrose agar (PDA; $2.7 \mathrm{~g}$ of potato dextrose powder, $15 \mathrm{~g}$ of sugar, $10 \mathrm{~g}$ of agar 

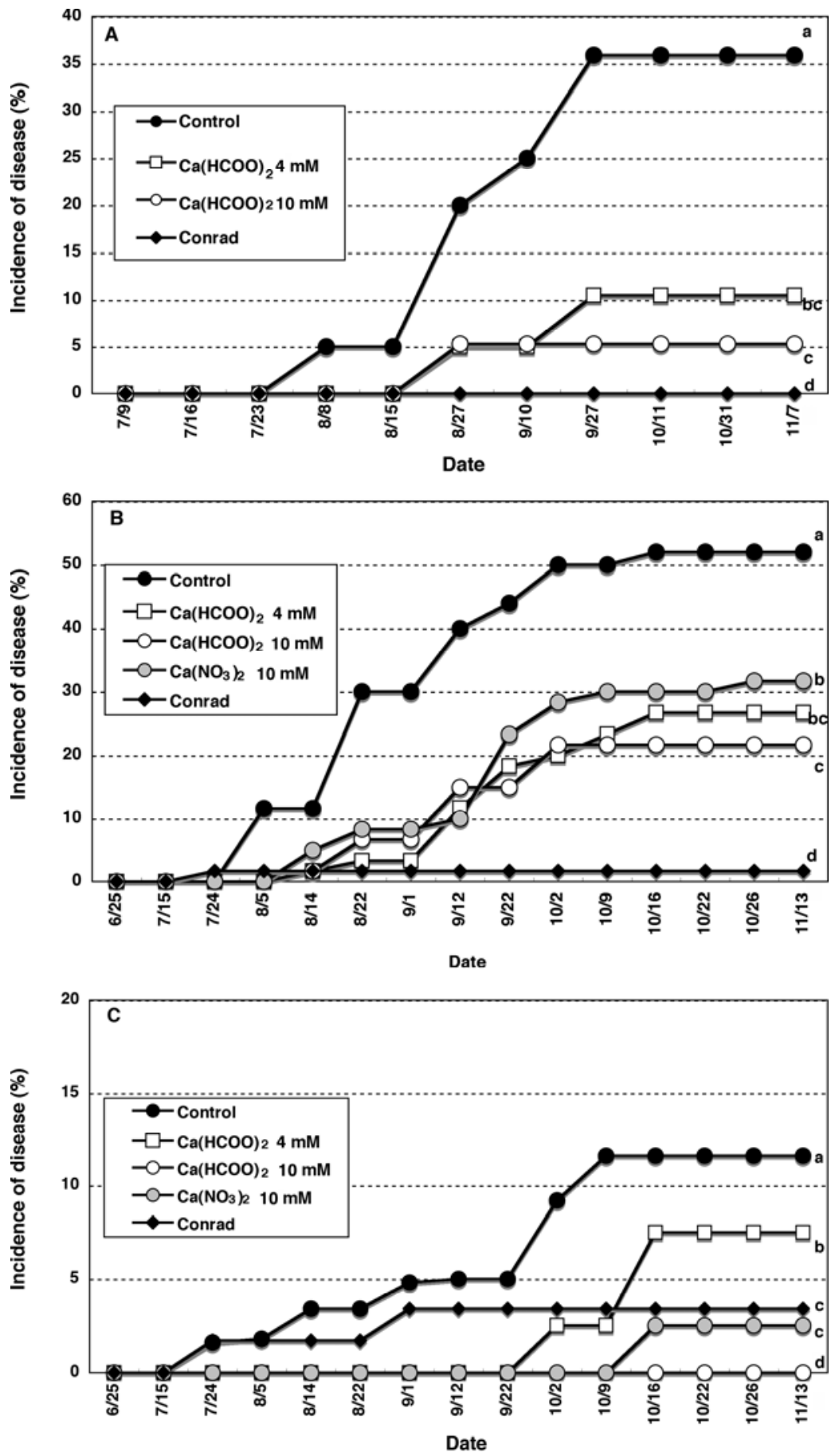

Fig. 1. Field experiments evaluating the effect of calcium applications on the reduction of Phytophthora stem rot disease of soybean in three fields: A, Kawakita K1 in 2007, B, Yakami in 2008, and C, Kawakita K2 in 2008. Calcium solution was amended prior to transplanting and 14 days after transplanting. Cultivar Conrad, which shows high partial resistance, was also tested to compare with the effects of calcium applications. Different letters denote significant differences according to an ANOVA and least significant difference $(P<0.05)$. per liter of distilled water) (Nissui, Tokyo, Japan). Disease incidence was recorded 7 days after inoculation (equivalent to the time of sampling for scanning electron study). The eight inoculated or noninoculated stems of soybean treated with or without calcium solutions $[0$ and $10 \mathrm{mM}$ of $\mathrm{Ca}(\mathrm{HCOO})_{2}-\mathrm{A}$ and $\left.\mathrm{Ca}\left(\mathrm{NO}_{3}\right)_{2}\right]$ on the agar medium in each test bottle were cut using a surgical blade (Feather safety razor, Tokyo, Japan) into 1-mm-thick sections, and at least four stems per each bottle were observed using a variable pressure-scanning electron microscope (VP-SEM) (US-1500, Hitachi HighTechnologies, Osaka, Japan) at a cooling stage temperature of $-10^{\circ} \mathrm{C}(15000 \mathrm{~V})$. The X-ray mapping images of calcium, potassium, sulfate, phosphate, and magnesium on each fresh sample were carried out using an Energy Dispersive X-ray spectroscopy (EDX) spectrometer (EX450; Horiba, Kyoto, Japan) according to the manufacturer's instructions. The measurements were conducted three times in three replications.

Statistical analysis. All results were analyzed with analysis of variance (ANOVA) and Fisher's least significant differences (LSD) test using Microsoft Excel software for Macintosh.

\section{RESULTS}

Field experiments. The stems of soybean plants infected by $P$. sojae appeared water-soaked and turned brown, and the infection resulted in wilting and death of plants during the field experiments in both 2007 and 2008. The mean disease incidence of nontreated plants of cv. Tanbakuro at Kawakita K1 in 2007 was $35.9 \%$ at 140 days after transplanting. Concentrations of 4 and $10 \mathrm{mM} \mathrm{Ca}(\mathrm{HCOO})_{2}-\mathrm{A}$ (Suicaru) significantly reduced disease incidence to 10.5 and $5.3 \%$, respectively $(P<$ 0.05) (Fig. 1A). No disease symptoms were observed on nontreated plants of cv. Conrad with the partial resistance trait during the field experiment in 2007.

In 2008, disease incidence of nontreated soybean plants was $52.0 \%$ at Yakami and $11.7 \%$ at Kawakita K2 at 140 days after transplanting (Fig. 1B and C). Concentrations of 4 and $10 \mathrm{mM} \mathrm{Ca}(\mathrm{HCOO})_{2}-\mathrm{A}$ (Suicaru) reduced disease incidence $(P<0.05)$ to 26.7 and $21.7 \%$ at Yakami, and 7.5 and $0 \%$ at Kawakita $\mathrm{K} 2$, compared with the

Table 1. Chemical properties of soils in three experimental fields in Hyogo from 2007 to $2008^{\mathrm{z}}$

\begin{tabular}{|c|c|c|c|c|c|c|c|c|c|c|c|c|c|c|c|c|c|c|c|}
\hline \multirow[b]{2}{*}{ Year } & \multirow[b]{2}{*}{ Field } & \multirow{2}{*}{$\begin{array}{c}\text { Disease } \\
\text { incidence } \\
(\%)\end{array}$} & \multirow[b]{2}{*}{ pH } & \multirow{2}{*}{$\begin{array}{c}\mathrm{EC} \\
(\mathrm{mS} / \mathrm{cm})\end{array}$} & \multirow{2}{*}{$\begin{array}{l}\text { CEC } \\
(\mathrm{me} / \\
100 \mathrm{~g})\end{array}$} & \multicolumn{3}{|c|}{$\begin{array}{c}\text { Exchangeable cation } \\
\quad(\mathrm{mg} / 100 \mathrm{~g})\end{array}$} & \multirow[b]{2}{*}{$\mathrm{P}_{2} \mathrm{O}_{5}$} & \multirow[b]{2}{*}{ PAC } & \multirow[b]{2}{*}{$\mathrm{Ca} / \mathrm{Mg}$} & \multirow[b]{2}{*}{$\mathrm{Mg} / \mathrm{K}$} & \multirow{2}{*}{$\begin{array}{l}\text { LSP } \\
(\%)\end{array}$} & \multirow{2}{*}{$\begin{array}{l}\text { BSP } \\
(\%)\end{array}$} & \multicolumn{4}{|c|}{ Micronutrient (ppm) } & \multirow{2}{*}{$\begin{array}{l}\text { N (mg/ } \\
100 \mathrm{~g})\end{array}$} \\
\hline & & & & & & $\mathrm{CaO}$ & MgO & $\mathbf{K}_{2} \mathbf{O}$ & & & & & & & $\mathbf{C u}$ & $\mathbf{Z n}$ & Mn & B & \\
\hline 2007 & Kawakita K1 & 35.9 & 5.6 & 0.22 & 16.4 & 208.4 & 32.9 & 27.9 & 13.1 & 857 & 4.6 & 2.8 & 45.3 & 58.8 & 6.43 & 5.50 & 137.96 & 0.82 & 4.87 \\
\hline 2008 & Yakami & 52.0 & 6.0 & 0.33 & 13.6 & 183.4 & 32.4 & 26.6 & 32.6 & 658 & 4.1 & 2.8 & 48.2 & 64.3 & 5.70 & 4.67 & 86.04 & 0.57 & 18.66 \\
\hline 2008 & Kawakita K2 & 11.7 & 6.7 & 0.32 & 18.9 & 277.8 & 55.9 & 31.7 & 32.3 & 756 & 3.6 & 4.1 & 52.4 & 70.6 & 6.62 & 7.23 & 88.01 & 1.53 & 6.34 \\
\hline
\end{tabular}

${ }^{\mathrm{z}}$ EC: electrical conductivity; CEC: cation exchange capacity; $\mathrm{P}_{2} \mathrm{O}_{5}$ : available phosphorus (Truog- $\mathrm{P}_{2} \mathrm{O}_{5}$ ); PAC: phosphate absorption coefficient; LSP: lime saturation percentage; BSP: base saturation percentage; $\mathrm{N}$ : hot water soluble nitrogen. Each soil was sampled from five random locations ( $20 \mathrm{~cm}$ deep) in each field. Numbers are the means of the five samples taken over $500 \mathrm{~g}$ per field in May of each year. Samples were mixed prior to analysis to provide a single value representative of each location. 
nontreated plants. When $10 \mathrm{mM} \mathrm{Ca}\left(\mathrm{NO}_{3}\right)_{2}$ was applied, incidence of disease significantly decreased to $31.7 \%$ at Yakami and $2.5 \%$ at Kawakita K2, compared to the controls $(P<0.05)$. The effect of both calcium amendments on disease incidence was limited at the Yakami field, which had a higher disease incidence $(52.0 \%)$ on control plants overall. The incidence of disease of cv. Conrad was $1.7 \%$ at Yakami and $3.4 \%$ at Kawakita K2. Application of $10 \mathrm{mM}$ $\mathrm{Ca}(\mathrm{HCOO})_{2}-\mathrm{A}$ was more effective for reducing disease incidence at all three locations compared with the $4 \mathrm{mM} \mathrm{Ca}(\mathrm{HCOO})_{2}-\mathrm{A}$ and $10 \mathrm{mM} \mathrm{Ca}\left(\mathrm{NO}_{3}\right)_{2}$ applications.

Chemical properties of soils. Soil derived from Kawakita K1 in 2007 and Yakami in 2008, which showed higher levels of disease incidence (35.9 and 52.0\%), had lower levels of $\mathrm{pH}, \mathrm{CEC}$, exchangeable cations $\left(\mathrm{CaO}, \mathrm{MgO}\right.$, and $\left.\mathrm{K}_{2} \mathrm{O}\right)$, lime saturation percentage (LSP), base saturation percentage (BSP), and micronutrients $(\mathrm{Cu}$, $\mathrm{Zn}, \mathrm{Mn}$, and B) than Kawakita K2, with an incidence of $11.7 \%$ (Table 1). Soil taken from Yakami, with $52.0 \%$ disease incidence in the control plants, had a higher level of nitrogen (Table 1).

Pathotypes of $P$. sojae isolates. Cvs. Tanbakuro and Williams (rps) were sus- ceptible to all 30 isolates obtained during the test, and all of the isolates were identified as $P$. sojae and were strongly virulent on those cultivars (90 to 100\%). No intermediate or inconsistent responses occurred on any of the differential cultivars. P. sojae race 39 (14), which was virulent on Rpsla, Rps1b, Rps1c, Rps1k, Rps2, Rps3a, Rps3b, Rps3c, Rps4, Rps5, Rps6, Rps7, and Rps8, was the most prevalent at Kawakita K1 and Kawakita K2 fields in both 2007 and 2008 (Table 2). P. sojae isolates, which were virulent on Rpslb, Rps2, Rps3a, Rps3b, Rps3c, Rps4, Rps5, Rps6, Rps7, and Rps8, tended to be dominant in the Yakami area in 2008, and was not identical to any of 55 races reported in the United States (14).

Effect of calcium applications on plant traits and seed yields. The effect of calcium applications on plant traits and seed yields was similar in the second experiment (at Yakami) to those in the first experiment (at Kawakita K2), and overall seed quality was more variable from noninfected plants in plots at Yakami. No significant differences in plant traits of flowering time, maturity, and stem diameter were observed between plants treated with calcium solutions and nontreated controls (Table 3). There were some differences in

Table 2. Pathotypes of Phytophthora sojae isolated from three experimental fields in Hyogo in 2007 to 2008

\begin{tabular}{lcclc}
\hline Name of field & Year & Race $^{\mathbf{y}}$ & Virulence formula $^{\mathbf{z}}$ & No. of isolates \\
\hline Kawakita K1 & 2007 & 39 & 1a, 1b, 1c, 1k, 2, 3a, 3b, 3c, 4, 5, 6, 7, 8 & 9 \\
& & ND & 1b, 2, 3a, 3b, 3c, 4, 5, 6, 7, 8 & 1 \\
Yakami & 2008 & ND & 1b, 2, 3a, 3b, 3c, 4, 5, 6, 7, 8 & 10 \\
Kawakita K2 & 2008 & 39 & $1 \mathrm{a}, 1 \mathrm{~b}, 1 \mathrm{c}, 1 \mathrm{k}, 2,3 \mathrm{a}, 3 \mathrm{~b}, 3 \mathrm{c}, 4,5,6,7,8$ & 10 \\
\hline
\end{tabular}

${ }^{y}$ Race of each isolate was determined by the reactions of standard sets of 8 of the 14 Rps differentials, which includes Rpsla, Rpslb, Rpslc, Rpsld, Rpslk, Rps3a, Rps6, and Rps7 (14). Race 39 is determined based on the virulence pathotypes reported by Grau et al. (14). ND, P. sojae isolate(s), which were virulent on Rps 1b, Rps2, Rps3a, Rps3b, Rps3c, Rps4, Rps5, Rps6, Rps7, and Rps8, tended to be dominant in the Yakami area in 2008, and was not identical to any of 55 races reported in the United States (14).

${ }^{\mathrm{z}}$ The pathotype of each isolate was examined on the following 14 differentials: L88-8470 (Rpsla), L77-1863 (Rpslb), L75-3735 (Rpslc), PI103091 (Rpsld), L77-1794 (Rpslk), L76-1988 (Rps2), L83-570 (Rps3a), L91-8347 (Rps3b), L92-7857 (Rps3c), L85-2352 (Rps4), L85-3059 (Rps5), L891581 (Rps6), L93-3258 (Rps7), and PI399073 (Rps8). plant height and number of nodes and pods between plants amended with calcium compounds and control plants. In most cases, the calcium application increased plant height and number of nodes and pods, compared to the nontreated control plants.

There were no differences between seed weights per 100 seeds when using different concentrations of calcium compounds. Although 4 and $10 \mathrm{mM} \mathrm{Ca}(\mathrm{HCOO})_{2}$ increased total seed yield and good seed yield per plant, $10 \mathrm{mM} \mathrm{Ca}\left(\mathrm{NO}_{3}\right)_{2}$ did not increase yield. All calcium treatments decreased the weight of low quality soybean seeds. Four mM Ca(HCOO) $)_{2}$ was the most effective for increasing number of plant nodes and pods, and seed yield per plant.

Scanning electron microscopy. Noninoculated soybean plants grew well in each treatment. All nontreated control plants were infected with $P$. sojae and had stem rot symptoms 7 days after inoculation (equivalent to the time of sampling for scanning electron study); $68.9 \%$ of the plants were dead during the experiments. At the same time, soybean plants treated with calcium solutions had no stem rot phases. A concentration of $10 \mathrm{mM}$ $\mathrm{Ca}(\mathrm{HCOO})_{2}-\mathrm{A}$ (Suicaru) and $\mathrm{Ca}\left(\mathrm{NO}_{3}\right)_{2}$ significantly reduced disease incidence to $0 \%$ compared with the nontreated plants $(P$ $<0.05)$. In nontreated control stems, fungal hyphae colonized the cuticle, epidermis, cortex layers, and pith of the soybean seedlings (Fig. 2A). In Ca-treated stems, fungal hyphae penetrated the cuticle and epidermal layer of plants treated with 10 $\mathrm{mM} \mathrm{Ca}(\mathrm{HCOO})_{2}$, but fungal penetration of the cortex layer appeared to be prevented, as shown by the arrow in Figure 3A. A cross-section of the stem and the distribution of calcium are shown in Figure 3A to $\mathrm{D}$, respectively. Calcium crystals were observed around the xylem and cambium in inoculated plants treated with $10 \mathrm{mM}$ $\mathrm{Ca}(\mathrm{HCOO})_{2}$, although the calcium crystals were not visualized in the nontreated con-

Table 3. Plant traits and seed yields of soybean cv. Tanbakuro treated at young seedling stage with two applications of different calcium solutions

\begin{tabular}{|c|c|c|c|c|c|c|c|c|c|c|}
\hline \multirow[b]{2}{*}{ Treatment } & \multicolumn{6}{|c|}{ Plant trait } & \multicolumn{4}{|c|}{ Yield per plant } \\
\hline & Floweringp & Maturity $q$ & $\begin{array}{l}\text { Plant ht. } \\
(\mathbf{c m})^{\mathrm{r}}\end{array}$ & $\begin{array}{l}\text { Diam. main } \\
\text { stem }(\mathrm{cm})^{\mathrm{s}}\end{array}$ & $\begin{array}{l}\text { No. of } \\
\text { nodes }^{t}\end{array}$ & $\begin{array}{l}\text { No. of } \\
\text { pods }\end{array}$ & $\begin{array}{l}\text { Total seed } \\
\text { yield }(\mathrm{g})^{\mathrm{v}}\end{array}$ & $\begin{array}{l}\text { Low qual. } \\
\text { seed }(\mathrm{g})^{\mathrm{w}}\end{array}$ & $\begin{array}{l}\text { Good seed } \\
\text { yield }(\mathrm{g})^{\mathrm{x}}\end{array}$ & $\begin{array}{l}\text { Wt./100 } \\
\text { seed }(g)^{y}\end{array}$ \\
\hline Control & 6 Aug & $6 \mathrm{Dec}$ & $72.6 \mathrm{a}^{\mathrm{z}}$ & 2.0 & $15.0 \mathrm{a}$ & $224.4 \mathrm{a}$ & $205.7 \mathrm{a}$ & $38.1 \mathrm{a}$ & $167.7 \mathrm{a}$ & $72.4 \mathrm{a}$ \\
\hline $4 \mathrm{mM} \mathrm{Ca}(\mathrm{HCOO})_{2}$ & 6 Aug & $6 \mathrm{Dec}$ & $75.9 \mathrm{~b}$ & 2.0 & $17.3 \mathrm{~b}$ & $265.3 \mathrm{~b}$ & $248.6 \mathrm{~b}$ & $21.4 \mathrm{~b}$ & $227.2 \mathrm{~b}$ & $73.2 \mathrm{a}$ \\
\hline $10 \mathrm{mM} \mathrm{Ca}(\mathrm{HCOO})_{2}$ & 6 Aug & $6 \mathrm{Dec}$ & $77.7 \mathrm{~b}$ & 2.0 & $17.1 \mathrm{~b}$ & $241.8 \mathrm{c}$ & $224.2 \mathrm{c}$ & $24.0 \mathrm{~b}$ & $200.3 \mathrm{~b}$ & $74.3 \mathrm{a}$ \\
\hline $10 \mathrm{mM} \mathrm{Ca}\left(\mathrm{NO}_{3}\right)_{2}$ & 6 Aug & $6 \mathrm{Dec}$ & $79.0 \mathrm{~b}$ & 2.1 & $15.6 \mathrm{a}$ & $238.0 \mathrm{c}$ & $206.7 \mathrm{a}$ & $28.5 \mathrm{~b}$ & $178.2 \mathrm{a}$ & $74.2 \mathrm{a}$ \\
\hline
\end{tabular}

$\mathrm{p}$ Flowering was measured periodically in late July to early August.

${ }^{\mathrm{q}}$ Maturity was recorded when $95 \%$ of pods had obtained mature color.

${ }^{\mathrm{r}}$ Plant height was measured in late October as height of an average plant from ground level to the uppermost node.

${ }^{\mathrm{s}}$ Diameter of the main stem was measured in late October as the diameter at the cotyledonary node.

${ }^{t}$ Number of nodes per plant was counted after harvesting at the R8 stage.

" Number of pods per plant was counted after harvesting at the R8 stage.

${ }^{\mathrm{v}}$ Total seed yield per plant was measured after harvesting at the R8 stage.

${ }^{\text {w }}$ Soybean seed of low quality was evaluated visually based on degree of thinner, wrinkling, defective seed coats, and moldy or rotten seeds according to the guidelines by Tewari et al. (47), and it was weighted.

$x$ Good seed yield per plant was calculated as follows: total seed yield - soybean seed of low quality.

${ }^{y}$ Good seed weight per plant was measured as grams per 100 seeds.

${ }^{\mathrm{z}}$ Numbers are the means of 20 individual plants of all soybeans randomly collected from each plot. Different letters in a column denote significant differences according to an ANOVA and least significant difference $(P<0.05)$. 
trol plants. There was little accumulation of calcium at the pith, phloem, cortex, inside the penetration-stopping sites of $P$. sojae, and in the infected or colonized cuticle and epidermal layer of the plants treated with $10 \mathrm{mM} \mathrm{Ca}(\mathrm{HCOO})_{2}$ (Fig. 3A to $\mathrm{D})$ or at the corresponding sites of the nontreated control plants (Fig. 2B and C). Calcium accumulation in noninoculated soybean seedlings treated with $10 \mathrm{mM}$ $\mathrm{Ca}(\mathrm{HCOO})_{2}$ had the same pattern as that in
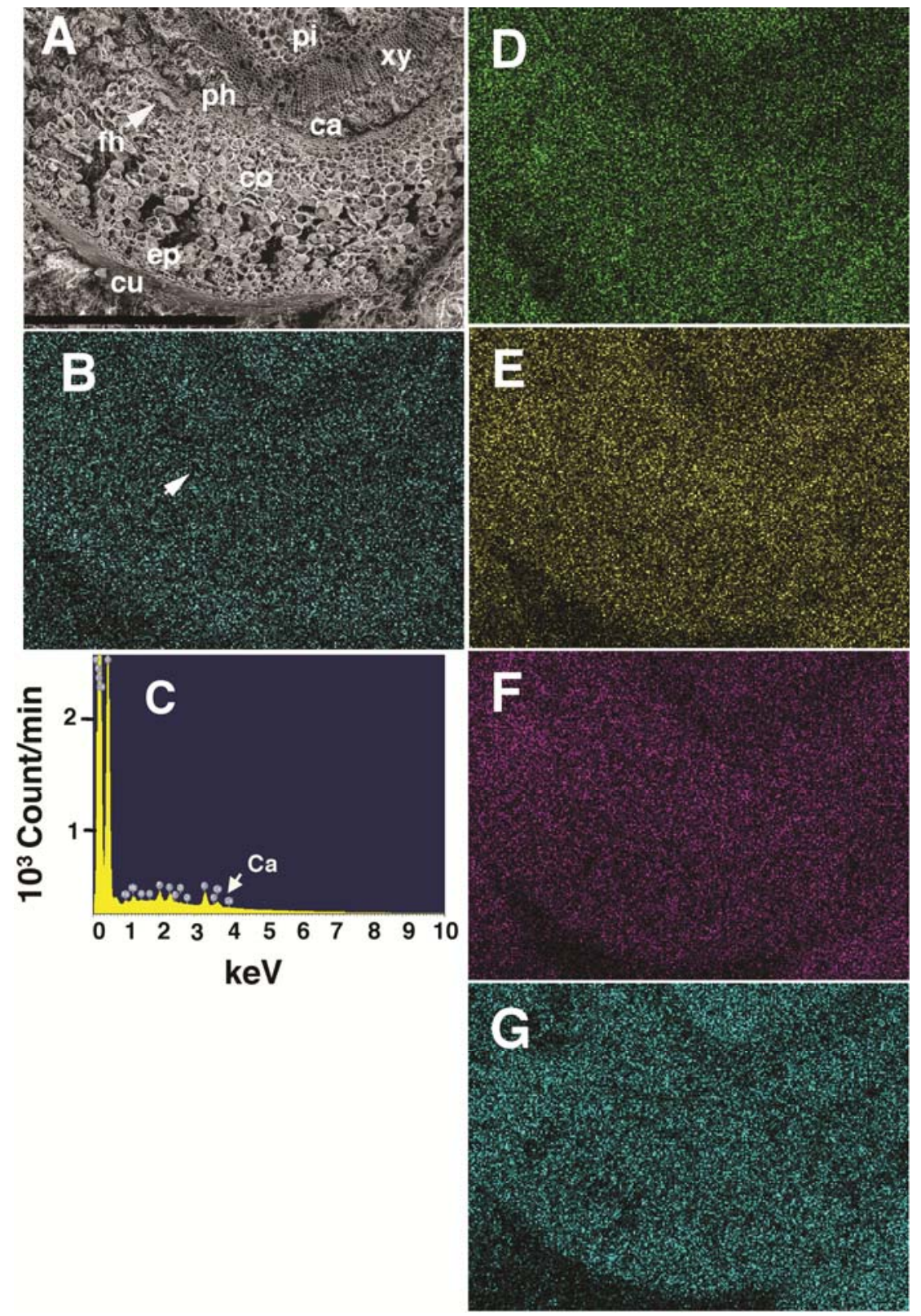

Fig. 2. Scanning electron micrographs, elemental spectrum analysis of several inorganic elements, and $\mathrm{X}$-ray mapping images of calcium in freshly inoculated soybean seedling treated without $\mathrm{Ca}(\mathrm{HCOO})_{2}$. Seven days after inoculation, the eight inoculated stems of soybean without calcium solutions on the agar medium in each test bottle were cut using a surgical blade into 1-mm-thick sections, and observed using a variable pressure-scanning electron microscope (VP-SEM) at a cooling stage temperature of $-10^{\circ} \mathrm{C}(15000 \mathrm{~V})$. X-ray mapping images of calcium, potassium, sulfate, phosphate, and magnesium on each fresh sample were carried out using an Energy Dispersive X-ray spectroscopy (EDX) spectrometer. $\mathbf{A}, \mathrm{Ca}(\mathrm{HCOO})_{2}$ - stem showing fungal hyphae that invaded cuticle, epidermis, cortex layer, and pith of the fresh soybean seedling. B, X-ray mapping of calcium in nontreated control plant. Arrow indicates site of elemental spectrum analysis. C, Elemental spectrum analysis indicating little accumulation of calcium in the fresh control plant. D to G, Elemental spectrum analysis indicating little accumulation of $\mathrm{K}, \mathrm{S}, \mathrm{P}$, and $\mathrm{Mg}$ in the inoculated soybean plant. cu, cuticle; co, cortex; ca, cambium; ep, epidermis; xy, xylem; ph, phloem; pi, pith; fh, fungal hyphae. Bar = $1 \mathrm{~mm}$.
$\mathrm{Ca}\left(\mathrm{NO}_{3}\right)_{2}$ were similar to those of plants treated with $\mathrm{Ca}(\mathrm{HCOO})_{2}$.

\section{DISCUSSION}

The environmental and health consequences of conventional fungicides have encouraged research on alternative disease control strategies. Plant production and protection that has less impact on the environment is desired by both producers and consumers. Information on plant nutrition in relation to disease occurrence is therefore needed to determine its value in disease management programs and to effect conventional agricultural practices.

Calcium is considered an effective inorganic element for reducing several diseases $(4,9,28,30,35,50,53)$, including diseases caused by Phytophthora spp. $(6,17,33,51)$. We previously reported that calcium application could reduce Phytophthora stem rot of soybean under laboratory conditions $(42,43)$. However, there have been no field trials that have tested calcium compounds for the control of Phytophthora stem rot on soybean.

In this study, $\mathrm{Ca}(\mathrm{HCOO})_{2}-\mathrm{A}$ (Suicaru) and $\mathrm{Ca}\left(\mathrm{NO}_{3}\right)_{2}$ were selected for the field experiments because these calcium compounds were effective in suppressing disease incidence in earlier experiments (42). $\mathrm{Ca}(\mathrm{HCOO})_{2}$ - $\mathrm{A}$ decreased incidence of disease by 1.4 to $48.3 \%$ in vitro, and by 5.8 to $29.9 \%$ in seedling bioassay experiments. $\mathrm{Ca}\left(\mathrm{NO}_{3}\right)_{2}$ reduced disease incidence by 5.5 to $53.6 \%$ in vitro. The present study has shown that, in the field, over two growing seasons, $10 \mathrm{mM} \mathrm{Ca}(\mathrm{HCOO})_{2}-\mathrm{A}$ was effective for reducing disease incidence (disease incidence $=0$ to $21.7 \%$ ) in comparison with the nontreated control plants $($ disease incidence $=11.7$ to $52.0 \%$ ) . There are only a few reports that have shown the potential for disease reduction with calcium formate $(1,5,34)$. This is the first report to verify that $\mathrm{Ca}(\mathrm{HCOO})_{2}$ has a suppressive effect on Phytophthora stem rot disease in the field. $\mathrm{Ca}\left(\mathrm{NO}_{3}\right)_{2}$ also was effective for reducing Phytophthora stem rot disease in the field, although not to the extent of $\mathrm{Ca}(\mathrm{HCOO})_{2}$. This result may be due to differences in calcium uptake mechanisms in the field.

Results from our field experiments were similar to those of the previous seedling tray assays and the agar medium inoculations (42); although the suppressive effects of calcium applications in the field were slightly decreased in comparison. The decreased suppressive effect relative to the in vitro studies might have been caused by the buffering effect of soils and antagonistic and/or synergistic activities between calcium and other inorganic elements in the fields (23). The microbial environment in the field also differs from that of an experimental situation due to the presence of many different microorganisms. It was reported that high-potassium and lowcalcium conditions increased disease 
caused by $P$. parasitica (16). In contrast, in this study $\mathrm{K} / \mathrm{Ca}$ was 0.15 at Yakami field (disease incidence $=52.0 \%), 0.14$ at $\mathrm{Ka}-$ wakita $\mathrm{K} 1$ (disease incidence $=35.0 \%$ ), and 0.11 at Kawakita K2 (disease incidence $=$ $11.7 \%$ ). The level of potassium in plants depends on the availability of calcium and magnesium. Calcium enhanced potassium availability (29). Further studies concerning physical and chemical properties of other soils infested with $P$. sojae should be examined to further elucidate the relationship between calcium and other elements and their relationship to disease levels.

Disease incidence in Kawakita K2 field was lower than that in the other two fields. Soil chemical analysis showed that soil taken from this field had higher levels of exchangeable cations including calcium, a higher LSP, and a higher BSP than the other two fields. It was reported that good calcium fertility is associated with strong cell walls that enhance disease resistance and the ability of the crop to maintain firm tissues (29). Our results suggest that balanced nutrients could be essential for plant resistance to the pathogen. Alternatively, unbalanced nutrients may result in increased susceptibility.

The calcium amendments $\left[\mathrm{Ca}(\mathrm{HCOO})_{2}\right.$ $\mathrm{A}$ and $\mathrm{Ca}\left(\mathrm{NO}_{3}\right)_{2}$ ] increased seed yields and reduced low quality seeds. The application of gypsum improved soybean quality through an increase in protein and $\mathrm{S}$ content, and in grain $\mathrm{P}, \mathrm{K}$, and $\mathrm{Ca}$ (7). The gypsum amendment also enhanced seed yields of soybean (2). This is the first result to show that $\mathrm{Ca}(\mathrm{HCOO})_{2}-\mathrm{A}$ and $\mathrm{Ca}\left(\mathrm{NO}_{3}\right)_{2}$ applications could increase seed yield and seed quality, as well reduce disease incidence. Research on the effects of calcium applications on plant growth and seed yields is an important aspect for refining practical agricultural production techniques, as well as for the management of Phytophthora stem rot of soybean.

The mechanisms by which disease is suppressed in the field have not been determined. Generally, soybean hypocotyl cells are infected 8 to $12 \mathrm{~h}$ after contact with $P$. sojae $(31,54)$. High levels (more than $4 \mathrm{mM}$ ) of several calcium solutions have been shown to decrease mycelial growth and inhibit release of zoospores (42). Increased calcium concentrations in soybean plants were associated with disease reduction (42). Previous studies have shown that disease suppression was due to increased resistance to the pathogen by increased levels of calcium in the cell wall region (9). In view of these findings, it was thought that the disease reduction shown in the present study was due to the multiple effects of direct suppression on zoospore release and fungal growth by the application of calcium solution at 14 days after transplanting in combination with the response of the host plant tissue to $\mathrm{Ca}(\mathrm{HCOO})_{2}-\mathrm{A}$ or $\mathrm{Ca}\left(\mathrm{NO}_{3}\right)_{2}$, and the increased resistance of cell walls strength-

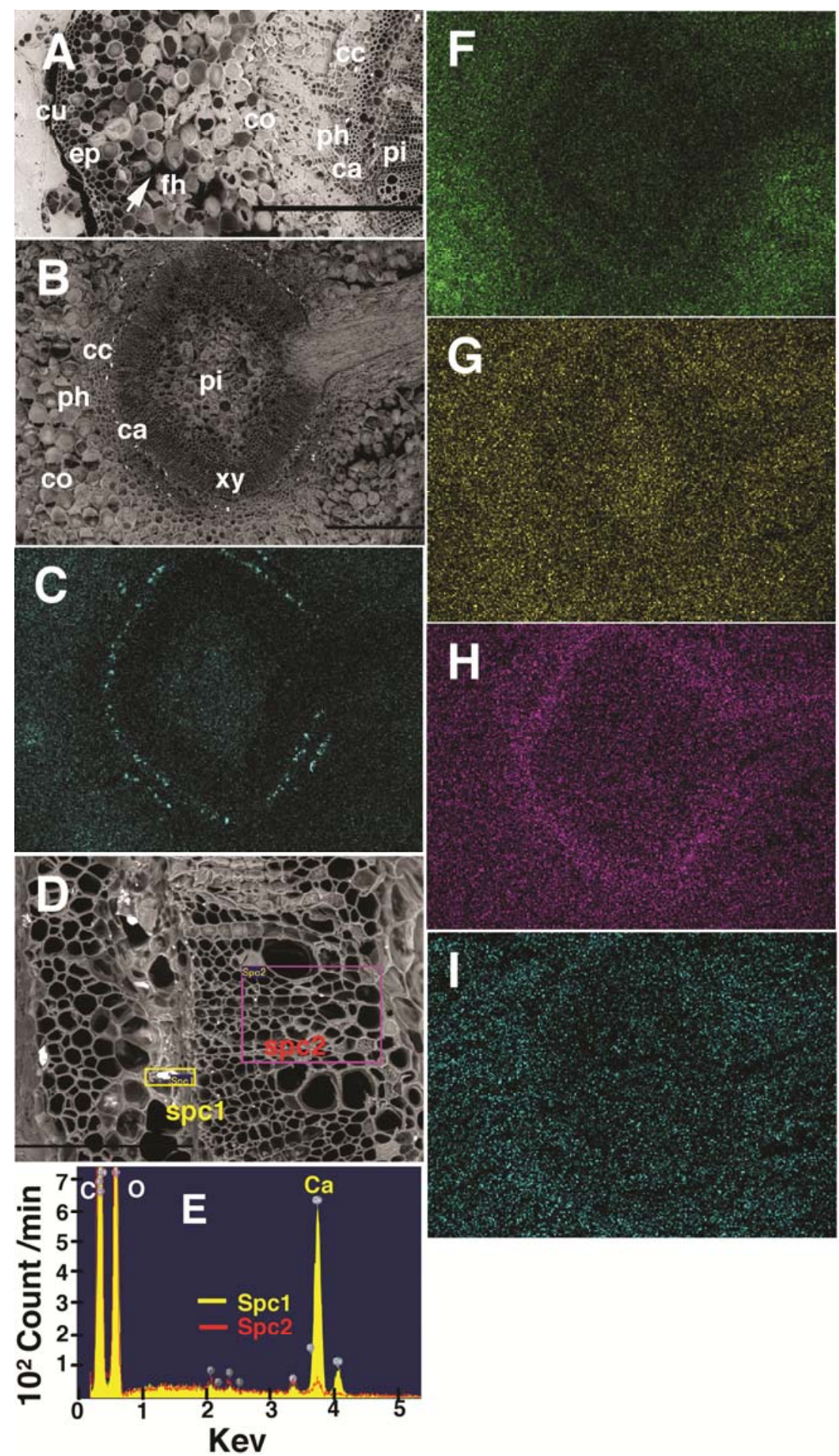

Fig. 3. Scanning electron micrographs, elemental spectrum analysis of several inorganic elements, and X-ray mapping images of calcium in fresh soybean seedlings treated with $10 \mathrm{mM} \mathrm{Ca}(\mathrm{HCOO})_{2}$. Seven days after inoculation, the eight inoculated stems of soybean treated with $10 \mathrm{mM} \mathrm{Ca}(\mathrm{HCOO})_{2}-\mathrm{A}$ on agar medium in each test bottle were cut using a surgical blade into 1-mm-thick sections, and observed using a variable pressure-scanning electron microscope (VP-SEM) at a cooling stage temperature of $-10^{\circ} \mathrm{C}(15000 \mathrm{~V})$. X-ray mapping images of calcium, potassium, sulfate, phosphate, and magnesium on each fresh sample were carried out using an Energy Dispersive X-ray spectroscopy (EDX) spectrometer. $\mathbf{A}$ and $\mathbf{B}, \mathrm{Ca}(\mathrm{HCOO})_{2}+$ stem showing inhibition of fungal hyphae to penetration inside the cortex layer indicated by arrow. C, X-ray mapping of calcium in fresh plant treated with $10 \mathrm{mM}$ $\mathrm{Ca}(\mathrm{HCOO})_{2}$. D, Calcium crystals were observed at cambium and xylem, in comparison to the untreated control (Fig. 2B). Spc1 and Spc2 indicate points of elemental spectrum analysis. E, Elemental spectrum analysis indicating a high level of calcium accumulation in soybean seedling treated with 10 $\mathrm{mM} \mathrm{Ca}(\mathrm{HCOO})_{2}$. Calcium crystals consist of $\mathrm{Ca}, \mathrm{C}$, and $\mathrm{O}$. F to I, Elemental spectrum analysis indicating little accumulation of $\mathrm{K}, \mathrm{S}, \mathrm{P}$, and $\mathrm{Mg}$ in the inoculated soybean plant treated with $10 \mathrm{mM}$ $\mathrm{Ca}(\mathrm{HCOO})_{2}$. cc, calcium crystal; cu, cuticle; co, cortex; ca, cambium; ep, epidermis; xy, xylem; ph, phloem; pi, pith; fh, fungal hyphae. Bars $=0.5 \mathrm{~mm}$. 
ened by the calcium application before transplanting.

To understand the response of the soybean plant tissue to calcium compounds, VP-SEM analysis with a cooling stage and an EDX spectrometer were used to monitor the localization of calcium in soybean seedlings. This system allows observation of water-containing samples under low vacuum conditions by suppressing vaporization of water and minimizing tissue damage, eliminating or reducing the need for conventional sample preparation such as fixation, dehydration, drying, and metal coating; it is also free from migration or leaching of original chemical compositions in samples during the course of dehydration and drying (19). To evaluate calcium localization precisely, this study used an agar medium as a base culture containing only $1.0 \%$ sugar without nutrient elements so as to eliminate or minimize the effects of other inorganic elements and varying $\mathrm{pH}$ differences (43). SEM observation of the stems of the soybean plants revealed an increased calcium content in the cambium and xylem of seedlings treated with 10 $\mathrm{mM} \mathrm{Ca}(\mathrm{HCOO})_{2}-\mathrm{A}$ or $\mathrm{Ca}\left(\mathrm{NO}_{3}\right)_{2}$. Compared to the controls, treated plants contained numerous calcium crystals and were associated spatially with disease reduction. Fungal penetration was completely inhibited at these sites. The accumulation of other inorganic elements such as $\mathrm{K}, \mathrm{S}, \mathrm{P}$, and $\mathrm{Mg}$ was not observed at the penetration sites of $P$. sojae. These results indicated that calcium-rich areas are more resistant to invasion by $P$. sojae. Our results also support the assertion that soybean seedlings could acquire resistance to the pathogen, since the calcium content in plants increased prior to infection by $P$. sojae in the field. Further studies are necessary for determining the role of calcium crystals and their physiological significance in this host-pathogen interaction.

Two applications of $\mathrm{Ca}(\mathrm{HCOO})_{2}-\mathrm{A}$ and $\mathrm{Ca}\left(\mathrm{NO}_{3}\right)_{2}$ in the early growing stage of $\mathrm{cv}$. Tanbakuro resulted in a disease suppressive effect, delaying the onset of disease in all three fields. The amount of disease reduction was affected by the calcium concentration in the solution. First symptoms on plants treated with 0 (control), 4 , and $10 \mathrm{mM} \mathrm{Ca}(\mathrm{HCOO})_{2}$-A at Kawakita $\mathrm{K} 1$ field in 2007 were observed on $8 \mathrm{Au}-$ gust, 15 August, and 27 August, respectively. At Kawakita K2, first symptoms on nontreated control plants were observed on 24 July 2008, whereas application of 4 $\mathrm{mM} \mathrm{Ca}(\mathrm{HCOO})_{2}$ - $\mathrm{A}$ and $10 \mathrm{mM} \mathrm{Ca}\left(\mathrm{NO}_{3}\right)_{2}$ delayed expression of first symptoms until 2 and 9 October, respectively. Disease incidence on $\mathrm{cv}$. Tanbakuro amended with $10 \mathrm{mM} \mathrm{Ca}(\mathrm{HCOO})_{2}-\mathrm{A}$ was $0 \%$ in this field. At Yakami in 2008, first symptoms on plants treated with 0 (control), 4 , and 10 $\mathrm{mM} \mathrm{Ca}(\mathrm{HCOO})_{2}-\mathrm{A}$ and $10 \mathrm{mM} \mathrm{Ca}\left(\mathrm{NO}_{3}\right)_{2}$ were noted on 5 August, 14 August, and 14 August, respectively. In our previous re- port, VP-SEM observation with fresh samples indicated marked accumulation of potassium at the penetration-stopping sites of $P$. sojae in the cortex layer of soybean plants treated with $30 \mathrm{mM} \mathrm{KNO} 3$ (41). Maekawa et al. (27), using VP-SEM analysis, reported that silicon accumulated near the penetration pegs of Magnaporthe grisea on fresh paddy rice leaves. In the present study, increased calcium accumulation near the penetration-stopping sites was not observed. This result may indicate that calcium crystals might be one form of calcium ion storage, and that the element is available to plant tissues during the expression of the disease resistance response. If so, if the calcium crystals in plants disappear due to calcium mobilization and incorporation into tissues, then Phytophthora stem rot disease would ultimately increase at some point in time as calcium mobilization decreased. A more thorough timecourse study of calcium fluxes in relation to host susceptibility could help elucidate the role of calcium sequestration and mobilization in mediating this suppressive effect against $P$. sojae.

Two pathotypes of $P$. sojae (race 39 [virulent on Rpsla, Rpslb, Rpslc, Rpslk, Rps2, Rps3a, Rps3b, Rps3c, Rps4, Rps5, Rps6, and Rps7] and new pathotype [virulent on Rps 1b, Rps2, Rps3a, Rps3b, Rps $3 c$, Rps4, Rps5, Rps6, and Rps7]) were discovered in three experimental fields. Furthermore, all the isolates were virulent on $\mathrm{cv}$. PI399073 having Rps8, which was considered to be strongly resistant in the United States $(12,36)$. This is the first report of $P$. sojae isolates that could defeat Rps8. The calcium applications were effective in reducing disease incidence in all three fields. Therefore, calcium amendments could suppress disease incidence independent of the pathotype composition in the field. However, the effect of calcium amendments on disease incidence was limited at the Yakami field, where a new pathotype of $P$. sojae tended to be predominant. This may be due to pathotype differences and variation in sensitivity to calcium compounds. It was reported that the response of pathogens to calcium supplementation was variable within a population $(4,8)$. Biggs (4) reported that there was significant variation among isolates and calcium salts on the growth of Botryosphaeria dothidea in liquid culture. Chardonnet et al. (8) reported evidence that the biological and statistical variability can be affected by the $B$. cinerea isolate, although $\mathrm{Ca}$ treatment of apples reduced decay caused by all three $B$. cinerea isolates.

Disease incidence in nontreated control plants of cv. Conrad with the partial resistance trait ranged from 0 to $3.4 \%$ between 2007 and 2008, showing lower levels of disease incidence than nontreated control plants or calcium-treated plants of cv. Tanbakuro. This result supports previous findings that demonstrated partial resistance in this cultivar $(10,38)$. Although this cultivar may be useful as a parental line for breeding, calcium application was considered a more effective and suitable method for reducing disease incidence in Japan. Disease management strategies require immediate attention and implementation in the Hyogo district; it takes many years to breed new $P$. sojae-resistant cultivars of black soybean having the desirable traits mentioned above.

Further research should focus on the central mechanisms involved in disease reduction due to calcium application. Calcium ion is a ubiquitous intracellular second messenger during plant defense responses, and its signal is one of the earliest events in challenged cells. The $\mathrm{Ca}^{2+}$ signal also is necessary for the activation of plant defense responses such as oxidative burst, phytoalexin synthesis and accumulation, induction of defense-related genes, and hypersensitive reaction-related cell death $(22,26)$. In order to answer this question, it would be necessary to examine gene expression related to plant defense reactions and signaling in soybean in response to calcium application and infection by $P$. sojae.

In conclusion, this study showed that applications of $\mathrm{Ca}(\mathrm{HCOO})_{2}-\mathrm{A}$ (Suicaru) and $\mathrm{Ca}\left(\mathrm{NO}_{3}\right)_{2}$ reduced Phytophthora stem rot of soybean in the fields where two different pathotypes existed, and affected resistance to $P$. sojae. Ten $\mathrm{mM}$ $\mathrm{Ca}(\mathrm{HCOO})_{2}-\mathrm{A}$ was the most effective treatment for disease management of Phytophthora stem rot. This effect might be mediated by a direct response of the host tissue to increased calcium, and possibly by a direct inhibition of fungal growth and zoospore release. SEM analysis with fresh soybean samples showed that calcium crystals were observed around the cambium and xylem of soybean seedlings treated with calcium solutions, suggesting that the calcium crystals may play an important role in calcium ion storage and its supply, as well as in inhibition of mycelial penetration. In combination with new resistant cultivars with the desirable characteristics of cv. Tanbakuro (45), we believe that these findings can contribute to effective control strategies for the integrated management of Phytophthora stem rot of soybean.

\section{ACKNOWLEDGMENTS}

We thank David Walker (USDA-ARS National Soybean Research Center) for reviewing this manuscript; Kiyotomo Futai, Toshiharu Onishi, and Eiji Hinomoto for collecting the diseased plants; Natsuko Ichieda, Kiyoji Kitagawa, Hirokazu Yamamoto, Nobuhiko Kondo, Ryou Yamamoto, Sanae Shikata, Tomoko Okudaira, Kozue Akamatsu, and Seiko Mori for supporting this study; and R. L. Nelson (USDA-ARS), Akiko Tazawa, Noriyuki Takada, and Yoko Yamashita for providing seeds of the soybean differential cultivars. This work was supported by a grant from the Ministry of Agriculture, Forestry and Fisheries of Japan (Genomics for Agricultural Innovation, DD-3113), and by a grant from the Hyogo Prefectural Government (Overseas training programs for young staff, 2007). 
LITERATURE CITED

1. Adaskaveg, J. E., Ogawa, J. M., and Feliciano, A. J. 1992. Comparisons of calcium-based and film-forming materials for control of brown rot of peach caused by Monilinia fructicola. (Abstr.) Phytopathology 82:1158.

2. Arihara, J., Nakayama, N., and Takahashi, M. 1999. Effect of gypsum application on grain yield of soybean. (In Japanese.) Jpn. J. Crop Sci. 68:40-41.

3. Baysal, F., Benitez, M.-S., Kleinhenz, M. D., Miller, S. A., and McSpadden Gardener, B. B. 2008. Field management effects on dampingoff and early season vigor of crops in a transitional organic cropping system. Phytopathology 98:562-570.

4. Biggs, A. R. 2004. Effect of inoculum concentration and calcium salts on infection of apple fruit by Botryosphaeria dothidea. Plant Dis. 88:147-151.

5. Biggs, A. R., El-Kholi, M. M., EI-Neshawy, S., and Nickerson, R. 1997. Effects of calcium salts on growth, polygalacturonase activity, and infection of peach fruit by Monilinia fructicola. Plant Dis. 81:399-403.

6. Broadbent, P., and Baker, K. F. 1974. Behavior of Phytophthora cinnamomi in soils suppressive and conductive to root rot. Aust. J. Agric. Res. 25:121-137.

7. Caires, E. F., Churka, S., Garbuio, F. J., Ferrari, R. A., and Norgano, M. A. 2006. Soybean yield and quality as a function of lime and gypsum applications. Sci. Agric. (Piracicaba Braz) 63:370-379.

8. Chardonnet, C. O., Sams, C. E., Trigiano, R. N., and Conway, W. S. 2000. Variability of three isolates of Botrytis cinerea affects the inhibitory effects of calcium on this fungus. Phytopathology 90:769-774.

9. Conway, W. S., Sams, C. E., Mcguire, R. G., and Kelman, A. 1992. Calcium treatment of apples and potatoes to reduce post-harvest decay. Plant Dis. 76:329-334.

10. Dorrance, A. E., McClure, S. A., and St. Martin, S. K. 2003. Effect of partial resistance on Phytophthora stem rot incidence and yield of soybean in Ohio. Plant Dis. 87:308-312.

11. Fehr, W. R., Caviness, C. E., Burmood, D. T., and Pennington, J. S. 1971. Stage development description for soybean Glycine $\max$ (L.) Merill. Crop Sci. 11:929-931.

12. Gordon, S. G., St. Martin, S. K., and Dorrance, A. E. 2006. Rps8 maps to a resistance gene rich region on soybean molecular linkage group F. Crop Sci. 46:168-173.

13. Goto, I., Muramoto, J., and Inaki, M. 1982. Application of inductively coupled plasma atomic emission spectrometry (ICP-AES) to soil analysis (Part 5): Determination of hot water soluble boron in soils by ICP-AES. (In Japanese with English summary.) Jpn. J. Soil Sci. Plant Nutr. 63:53-57.

14. Grau, C. R., Dorrance, A. E., Bond, J., and Russin, J. S. 2004. Fungal diseases. Pages 679763 in: Soybeans: Improvement, Production and Uses. 3rd ed. Agron. Monogr. H. R. Boerma and J. E. Specht, eds. American Society of Agronomy, Madison, WI.

15. Hirota, T., Fukushima, A., and Inoue, Y. 2006. Effects of blanching heat treatments on quality maintenance of Mukimame from immature black soybeans (edamame) 'Tanbakuro'. (In Japanese.) Kinki Chugoku Agric. Res. 9:25-28.

16. Huber, D. M. 1981. The use of fertilizers and organic amendments in the control of plant disease. Pages 357-394 in: CRC Handbook of Pest Management of Agriculture. Vol. 1. D. Pimentel, eds. CRC Press, Boca Raton, FL.

17. Huber, D. M., and Watson, R. D. 1970. Effect of organic amendment on soilborne diseases. Phytopathology 60:22-26.

18. Ichikawa, G., Okamoto, N., and Tanisaka, T. 2001. Toward early maturity breeding of the soybean cultivar 'Tanbaguro'; genetic analysis of ma- turity time. Kinki J. Crop Sci. Breed. 46:87-91.

19. Iwamoto, M., Wada, M., and Morita, Y. 1999. $\mathrm{X}$-ray microanalysis of papillar cells and pollen grains in the pollination process in Brassica using a variable-pressure scanning electron microscope. J. Electron Microsc. 48:909-917.

20. Kanto, T., Maekawa, K., and Aino, M. 2007. Suppression of conidial germination and appressorial formation by silicate treatment in powdery mildew of strawberry. J. Gen. Plant Pathol. 73:1-7.

21. Kaufmann, M. J., and Gerdemann, J. W. 1958. Root and stem rot of soybean caused by Phytophthora sojae n. sp. Phytopathology 48:201208.

22. Knight, M. R., Cambel, A. K., Smith, S. M., and Trewavas, A. J. 1991. Transgenic plant aequorin reports the effects of touch and cold shock and elicitors on cytoplasmic calcium. Nature 352:524-526.

23. Koohakan, P., Ikeda, H., Jaenaksorn, T., Tojo, M., and Kusakari, S. 2002. Effects of inorganic elements on the in-vitro Growth of Pythium aphanidermatatum (Edson) Fitzp. Microbes Environ. 17:91-97.

24. Kunoh, H. 1990. Ultrastructure and mobilization of ions near infection sites. Annu. Rev. Phytopathol. 28:93-111.

25. Laviolette, F. A., and Athow, K. L. 1981. Physiologic races of Phytophthora megasperma f. sp. glycinea in Indiana, 1973-1979. Plant Dis. 65:884-885.

26. Lecourieux, D., Ranjeva, R., and Pugin, A. 2006. Calcium in plant defence-signalling pathoways. New Phytol. 171:249-269.

27. Maekawa, K., Watanabe, K., Kanto, T., and Aino, M. 2002. Accumulation of silicon at the penetration sites of Magnaporthe grisea into rice leaves. (In Japanese with English summary.) Jpn. J. Soil Sci. Plant Nutr. 73:509-514.

28. Maloney, K., Pritts, M., Wilcox, W., and Kelly, M. J. 2005. Suppression of Phytophthora root rot in red raspberries with cultural practices and soil amendments. HortScience 40:1790-1795.

29. Marschner, H. 1995. Relationship between mineral nutrition and plant disease and pests. Pages 436-460 in: Mineral Nutrition of Higher Plants. 2nd ed. Academic Press, London, UK.

30. Messenger-Routh, B. J., Menge, J. A., and Pond, E. C. 1996. Effect of gypsum soil amendments on avocado root rot. (Abstr.) Phytopathology 86:S30.

31. Moy, P., Qutob, D., Chapman, B. P., Atkinson, I., and Gijzen, M. 2004. Patterns of gene expression upon infection of soybean plants by Phytophthora sojae. Mol. Plant-Microbe Interact. 17:1051-1062.

32. Muramoto, J., Goto, I., and Ninaki, M. 1992. Application of inductively coupled plasma atomic emission spectrometry (ICP-AES) to Soil Analysis (Part 6): Rapid analysis of exchangeable cations and cation exchange capacity (CEC) of soils by a shaking extraction method. (In Japanese with English summary.) Jpn. J. Soil Sci. Plant Nutr. 63:210-215.

33. Pegg, K. G. 1977. Biological control of Phytophthora cinnamomi root rot of avocado and pineapple in Queensland. Aust. Nurs. Assoc. Annu. Conf. Semin. Pap. 1977:7-12

34. Punja, Z. K., and Gaye, M. M. 1993. Influence of postharvest handling practices and dip treatment on development of black root rot on fresh market carrots. Plant Dis. 77:989-995.

35. Rahman, M., and Punja, Z. K. 2007. Calcium and plant disease. Pages 79-93 in: Mineral Nutrition and Plant Disease. L. E. Datnoff, W. H. Elmer, and D. M. Huber, eds. American Phytopathological Society, St. Paul, MN.

36. Sandhu, D., Schallock, K. G., Rivera-Velez, N., Lundeen, P., Cianzio, S., and Bhattacharyya, M. K. 2005. Soybean Phytophthora resistance gene Rps8 maps closely to the Rps3 region. J. Hered. 96:536-541.

37. Sato, A., and Takahashi, T. 1987. The causes of difference in the phosphorus adsorption coefficient between ammonium phosphate method and ortho-phosphoric acid method on HachiroGata reclaimed land soil. (In Japanese with English summary.) Jpn. J. Soil Sci. Plant Nutr. 59:609-611.

38. Schmitthenner, A. F. 1985. Problems and progress in control of Phytophthora root rot of soybean. Plant Dis. 69:362-368.

39. Schmitthenner, A. F. 1999. Phytophthora rot of soybean. Pages 39-42 in: Compendium of Soybean Diseases. 4th ed. G. L. Hartman, J. B. Sinclair, and J. C. Rupe, eds. American Phytopathological Society, St. Paul, MN.

40. Sugimoto, T., Aino, M., Sugimoto, M., and Watanabe, K. 2005. Reduction of Phytophthora stem rot disease on soybeans by the application of $\mathrm{CaCl}_{2}$ and $\mathrm{Ca}\left(\mathrm{NO}_{3}\right)_{2}$. J. Phytopathol. 153:536-543.

41. Sugimoto, T., Watanabe, K., Furiki, M., Yoshida, S., Aino, M., Kanto, T., and Irie, K. 2009. The effect of potassium nitrate on the reduction of Phytophthora stem rot disease of soybeans, the growth rate and zoospore release of Phy tophthora sojae. J. Phytopathol. 157:379-389.

42. Sugimoto, T., Watanabe, K., Yoshida, S Aino, M., Irie, K., Matoh, T., and Biggs, A. R. 2008. Select calcium compounds reduce the severity of Phytophthora stem rot of soybean. Plant Dis. 92:1559-1565.

43. Sugimoto, T., Watanabe, K., Yoshida, S. Aino, M., Matsuyama, M., Maekawa, K., and Irie, K. 2007. The effects of inorganic elements on the reduction of Phytophthora stem rot disease of soybean, the growth rate and zoospore release of Phytophthora sojae. J. Phytopathol. 155:97-107.

44. Sugimoto, T., Yoshida, S., Aino, M., Watanabe, K., Shiwaku, K., and Sugimoto, M. 2006. Race distribution of Phytophthora sojae on soybean in Hyogo, Japan. J. Gen. Plant Pathol. 72:92-97.

45. Sugimoto, T., Yoshida, S., Watanabe, K. Aino, M., Kanto, T., Maekawa, K., and Irie, K. 2008. Identification of SSR markers linked to the Phytophthora resistance gene Rpsl-d in soybean. Plant Breed. 127:154-159.

46. Takahashi, R., Ohmori, R., Kiyose, C., Momiyama, Y., Ohsuzu, F., and Kondo, K. 2005. Antioxidant activities of black and yellow soybeans against low density lipoprotein oxidation. J. Agric. Food Chem. 53:4578-4583.

47. Tewari, K., Sato, T., Abiko, M., Ohtake, N., Sueyoshi, K., Takahashi, Y., and Nagumo, Y. 2007. Analysis of the nitrogen nutrition of soybean plants with deep placement of coated urea and lime nitrogen. Soil Sci. Plant Nutr. 53:772-781

48. Truog, E. 1914. A new method for the determination of soil acidity. Science 40:246-248

49. Tsuchiya, S., Kodama, F., Akai, J., and Matsumura, Y. 1978. Occurrence of soybean stem rot caused by Phytophthora sojae megasperma var. sojae Hildebrand in Hokkaido. (Abstr. in Japanese.) Jpn. J. Phytopathol. 44:351.

50. Volpin, H., and Elad, Y. 1991. Influence of calcium nutrition on susceptibility of rose flowers to Botrytis blight. Phytopathology 81:1390-1394.

51. von Broembsen, S. L., and Deacon, J. W. 1997. Calcium interference with zoospore biology and infectivity of Phytophthora parasitica in nutrient irrigation solutions. Phytopathology 87:522-528.

52. Wrather, J. A., and Koenning, S. R. 2006. Estimates of disease effects on soybean yields in the United States 2003 to 2005. J. Nematol. 38:173-180

53. Yamazaki, H., and Hoshina, T. 1995. Calcium nutrition affects resistance of tomato seedlings to bacterial wilt. HortScience 30:91-93.

54. Yoshikawa, M., Yamauchi, K., and Masago, H. 1978. De novo messenger RNA and protein synthesis are required for phytoalexin-mediated disease resistance in soybean hypocotyls. Plant Physiol. 61:314-317. 